\title{
Pembagian Harta Bersama Perkawinan Akibat Perceraian Perkawinan Beda Agama yang Dicatatkan
}

\author{
Erma Kartika Timur, Abdul Rachmad Budiono, Hariyanto Susilo \\ Fakultas Hukum Universitas Brawijaya \\ ermakartikatimur@gmail.com
}

\begin{abstract}
Interfaith marriage in Indonesia be able to do with supplicate a determination to District Court, and then be listed in the Civil Registry Office. In case divorce occur on registered interfaith marriages, there is legal vagueness in regulation to divide joint property marriage, its relates with article 37 Constitution Number 1 of 1974 about Marriage. The purpose of this thesis is to description, identifying and analyzing the way to divide marriage property in interfaith marriage divorce, and also to review allowed or not to make choice of law that related to article 37. This thesis is a normative research with using statute approach and analytical approach. Based on the analysis of legal materials obtained, solution to divide joint property marriage on interfaith marriage better used husband religion or customary law, it is based from analysis using intergroups legal theory, receptive in complex theory, Idris Ramulyo opinion, Lanraad jurisprudence in Manado and also using grammatical interpretation about husband and wife position in article 31 and 34 marriage law. In case lawsuit happened, there is through the District Court after divorce decision was decided by judges. Choice of law is allowed based on equally principle.
\end{abstract}

Keywords: interfaith marriage, divorce, joint property marriage.

\begin{abstract}
Abstrak
Perkawinan beda agama di Indonesia dapat dilakukan dengan memohon penetapan dari Pengadilan Negeri, untuk kemudian dicatatkan di Kantor Catatan Sipil. Dalam hal terjadi perceraian pada perkawinan beda agama yang dicatatkan, terdapat kekaburan hukum pada ketentuan untuk membagi harta bersama perkawinan, berkaitan dengan Pasal 37 Undang-undang Nomor 1 Tahun 1974 tentang Perkawinan. Tujuan penulisan penelitian ini adalah untuk mendeskripsikan, mengidentifikasi dan menganalisis pembagian harta bersama dalam perceraian perkawinan beda agama serta untuk mengetahui diperbolehkan atau tidak dilakukannya pemilihan hukum untuk menyelesaikan pembagian harta bersama dalam perceraian perkawinan beda agama terkait dengan Pasal 37 UUP. Penelitian ini adalah penelitian yuridis normatif dengan menggunakan metode pendekatan Perundang-undangan (statute approach) serta pendekatan Analitis. Berdasarkan analisis terhadap bahan hukum yang diperoleh, penyelesaian pembagian harta bersama pada perkawinan beda agama dalam kondisi normal sepatutnya dibagi dengan ketentuan hukum agama atau adat dari pihak suami, hal tersebut berdasarkan dari hasil analisis menggunakan teori hukum antar golongan,
\end{abstract}


teori receptie in complexu, pendapat ahli Idris Ramulyo, Yurisprudensi Landraad di Manado serta interpretasi gramatikal terhadap kedudukan suami yang terdapat pada Pasal 31 dan 34 UUP. Dalam hal terjadi gugatan, maka dapat melalui Pengadilan Negeri, gugatan diajukan terpisah setelah adanya putusan perceraian. Pemilihan hukum oleh para pihak adalah diperbolehkan berdasarkan asas persamarataan.

\section{Kata kunci: perkawinan beda agama, perceraian, harta bersama.}

\section{Pendahuluan}

Pada saat ini, untuk melangsungkan pernikahan beda agama dimungkinkan untuk terjadi yaitu dengan jalan mengajukan permohonan perkawinan beda agama ke pengadilan negeri dengan tujuan agar Pengadilan mengeluarkan Penetapan sebagai bentuk dispensasi dari pengadilan negeri agar perkawinan beda agama tersebut dapat diizinkan secara hukum. Isi penetapan tersebut yaitu pemberian ijin kepada Pemohon untuk melangsungkan Perkawinan Beda Agama serta pemberian perintah kepada pegawai kantor Catatan Sipil untuk melakukan Pencatatan terhadap perkawinan tersebut kedalam Register Pencatatan Perkawian. Perkawinan yang dilangsungkan tersebut akan mengakibatkan hubungan hukum jika perkawinan tersebut dicatatkan, salah satunya adalah terhadap harta.
Tujuan perkawinan yang ideal menurut hukum nasional ataupun hukum agama pada realitanya sulit untuk diwujudkan, bahkan banyak pula terjadi kehidupan keluarga atau rumah tangga yang tidak bahagia. Keadaan perkawinan dapat menjadi buruk, sehingga dipandang dari segi apapun juga hubungan perkawinan tersebut lebih baik diputuskan daripada diteruskan. Perceraian yang terjadi pada perkawinan seagama tentu tidak menimbulkan persoalan karena segala ketentuannya sudah ditentukan dalam Undang-undang, namun apabila perceraian itu terjadi pada perkawinan antar atau beda agama maka akan menimbulkan suatu persoalan karena pada hakikatnya perkawinan beda agama tidak dikenal dalam UUP, jadi tidak ada ketentuan hukum yang dikhususkan terhadap perceraian perkawinan beda agama. Salah satu permasalahannya yaitu terhadap 
pembagian harta bersama pada perkawinan tersebut karena terdapat kekaburan hukum berkaitan dengan Pasal 37 UUP. Berdasarkan Pasal 37, segala harta benda termasuk harta bersama dalam perkawinan pembagiannya diatur menurut hukumnya masing-masing. Pada penjelasan Pasal 37 tersebut dinyatakan bahwa yang dimaksud dengan hukumnya masing-masing ialah hukum agama, hukum adat dan hukum-hukum lainnya.

\section{Rumusan Masalah}

1) Bagaimana pembagian harta bersama dalam perceraian perkawinan beda agama yang dicatatkan?

2) Apakah pada perceraian perkawinan beda agama dapat dilakukan pemilihan hukum untuk menyelesaikan pembagian harta bersama?

\section{Pembahasan}

Penelitian ini adalah penelitian yuridis normatif dikarenakan penelitian ini fokus pada peraturan tertulis, dan membutuhkan data yang sifatnya kepustakaan. Untuk menjawab rumusan masalah, penulis akan

mendeskripsikan, mengidentifikasi dan menganalisis menggunakan peraturan tertulis diantaranya KUHPerdata, UUP, KHI dan peraturan lain yang berhubungan.

Metode pendekatan yang digunakan pada penelitian ini adalah metode Pendekatan Perundangundangan (statute approach) dengan melakukan pendekatan terhadap KUHPerdata, UUP, dan KHI. Serta Pendekatan Analitis, yang menurut Johnny Ibrahim yaitu memahami maksud yang dikandung oleh istilah yang digunakan pada aturan perundang-undangan secara konsepsional. ${ }^{1}$ Pendekatan analitis digunakan untuk mengetahui bagaimana penerapan peraturan KUHPerdata dan UUP terhadap perceraian perkawinan beda agama yang dicatatkan, khususnya dalam hal pembagian harta bersama.

Teknik Analisa bahan hukum dalam penelitian ini yaitu dengan teknik preskriptif analitis, yaitu menemukan masalah untuk kemudian di identifikasi, dan dilakukan pembahasan dengan Bayu Media,2012), hlm. 310. 
menganalisis, serta menelaah perundang-undangan, berdasarkan teori dan menggunakan interpretasi. Interpretasi yang digunakan yaitu interpretasi gramatikal yaitu interpretasi dengan cara menguraikan ketentuan Undang-undang menurut Bahasa, susunan kata atau bunyinya, ${ }^{2}$

\section{Pembagian Harta Bersama Dalam Perceraian Perkawinan Beda Agama Yang Dicatatkan}

Pembagian harta bersama baru dapat dilakukan jika hubungan perkawinan telah terputus. Hubungan perkawinan itu dapat terputus dikarenakan salah satunya akibat adanya perceraian. Pada penelitian ini akan diuraikan pembagian harta bersama perkawinan beda agama dalam 2 keadaan yang berbeda, yaitu yang pertama ketika tidak timbul perselisihan atau dalam keadaan normal dan yang kedua dalam kondisi apabila timbul perselisihan dengan adanya gugatan.

1.1.) Dalam Kondisi Normal (Tidak Melalui Gugatan Pengadilan)

Pasal 37 UUP terkadang menimbulkan multitafsir karena pada

\footnotetext{
${ }^{2}$ Sudikno Mertokusumo, Mengenal Hukum, (Yogyakarta: Liberty,2003), hlm.170.
}

pasal tersebut dinyatakan "Bila perkawinan putus karena perceraian, harta benda diatur menurut hukumnya masing-masing”. Apalagi terhadap perkawinan beda agama itu sendiri sebenarnya tidak dikenal didalam UUP sehingga payung hukum terhadap perkawinan beda agama menjadi tidak jelas.

Dalam hal pembagian harta bersama perkawinan beda agama apabila terjadi perceraian memang belum terdapat ketentuan jelas yang mengaturnya. Apakah dibagi menurut hukum agama suami atau hukum agama istri, atau mungkin apabila terdapat perbedaan adat diantara keduanya hal tersebut dapat memberikan tambahan persoalan lagi. Hal tersebut akan menimbulkan hukum antar golongan yang meliputi hukum antar agama (interreligious) dan hukum antar adat (interlookal). ${ }^{3}$ Misalnya jika terjadi perkawinan campuran antara seorang perempuan Jawa beragama Islam dengan seorang Laki-laki Batak atau Minangkabau beragama Kristen. Kalau ini terjadi, kedudukan suami

\footnotetext{
${ }^{3}$ Wirjono Prodjodikoro, Hukum Antar Golongan di Indonesia, (Bandung: Sumur Bandung, 1981), hlm.93.
} 
atau istri dalam perkawinan menjadi agak kabur, yaitu apakah yang dianut peraturan parental (Jawa) atau patrilineal/kebapakan

(Batak)

maupun matrilineal/keibuan (Minangkabau). ${ }^{4}$ Corak masyarakat adat patrilineal, matrilineal serta parental memiliki perbedaan prinsip atas ketentuan harta bersama, seperti yang telah penulis jelaskan sebelumnya.

Permasalahan hukum antar golongan yang demikian tersebut timbul tidak terlepas dari frasa semboyan Negara Republik Indonesia "Bhinneka Tunggal Ika" karena negara ini terdiri atas beraneka ragam budaya, bahasa daerah, ras, suku bangsa, agama dan kepercayaan.

Pembagian harta bersama perkawinan beda agama termasuk kedalam ranah hatah intern, yaitu utamanya karena adanya perbedaan agama maupun jika terjadi perbedaan adat. Secara garis besar hatah intern ini dapat muncul dikarenakan:

1) Berbeda golongan penduduk Golongan penduduk Indonesia terbagi dalam tiga golongan, yaitu:

\footnotetext{
${ }^{4}$ Ibid, hlm.99.
}

a) Golongan Eropa dan yang dipersamakan (orang Jepang), Tunduk pada Hukum Eropa.

b) Golongan Timur Asing. Untuk Timur Asing Cina tunduk pada Hukum Perdata Eropa, kecuali masalah adopsi dan kongsi. Untuk Timur Asing bukan Cina tunduk pada hukum adat mereka.

c) Golongan Bumi Putera (Indonesia Asl), tunduk pada hukum adat. Dalam S. 1933 No. 49 pernyataan berlaku beberapa ketentuan dari buku kedua WvK (Hukum Dagang) terhadap orang orang Indonesia mulai 1 April 1933.

Karena adanya penggolongan rakyat berdasarkan ketentuan dalam pasal 163 dan 131 I.S, maka timbullah persoalan-persoalan tentang hukum yang harus dipakai jika orang dari golongan rakyat yang satu mengadakan hubungan dengan orang dari golongan-golongan rakyat yang lain.

2) Perbedaan Agama (Hukum Antar Agama) 
Apabila dalam suatu peristiwa hukum bertaut dua sistem hukum atau lebih disebabkan melibatkan orang - orang yang berlainan agama.

3) Berbeda lingkungan adatnya (Hukum Antar Adat)

Apabila dalam suatu peristiwa hukum tersangkut dua hukum atau lebih yang berlainan karena berlainan daerah dalam suatu Negara.

4) Berbeda wilayah (regio) jajahan (Hukum Antar Regio) Apabila dalam suatu peristiwa hukum terpaut dua hukum atau lebih yang berlainan karena perbedaan bagian dalam suatu Negara.

5) Perbedaan waktu berlakunya hukum (Hukum Antar Waktu) Apabila dalam suatu peristiwa hukum terpaut dau sistem hukum yang berlainan dalam satu Negara namun berbeda waktu berlakunya.

Untuk menentukan hukum manakah yang dipilih guna pembagian harta bersama tersebut maka harus ditinjau faktor-faktor penentu yang disebut "titik taut penentu" atau disebut juga aanknopingspunten. ${ }^{5}$ Titik taut penentu adalah bertemunya dua kaidah atau dua sistem hukum yang pada mulanya terpisah dan berbeda, disebabkan berbagai faktor, dua atau lebih kaidah atau sistem hukum bertemu pada satu titik singgung. Fungsi titik pertautan adalah sebagai metoda dalam rangka menelusuri indikator-indikator untuk dapat menentukan apakah suatu hubungan hukum diantara subjek-subjek hukum dapat digolongkan sebagai hukum perselisihan. ${ }^{6}$

Hukum manakah yang harus dipilih tergantung daripada "titik taut penentu" tersebut. Usaha untuk menemukan titik taut penentu ini merupakan salah satu bagian terpenting untuk dapat menyelesaikan persoalan tersebut. Titik pertautan dibedakan menjadi dua, yaitu:

1) Titik Pertautan Primer (Titik Taut Pembeda)

\footnotetext{
${ }^{5}$ Sudargo Gautama, Hukum Antar
} Golongan: Suatu Pengantar, (Jakarta: Ichtiar Baru Van Hoeve, 1993), hlm.87.

${ }^{6}$ Eman Suparman, Hukum Perselisihan (Konflik Kompetensi dan Pluralisme Hukum Orang Pribumi), (Bandung: PT. Refika Aditama,2009), hlm.51. 
Titik Taut Primer menurut Gouwgioksiong adalah hal-hal yang merupakan tanda akan adanya persoalan Hukum Antar Golongan. ${ }^{7}$ Menurut Prof. Eman Suparman, Titik Taut Primer merupakan indikator pembeda berupa faktor-faktor dan/ keadaan-keadaan yang menunjukkan bahwa suatu hubungan hukum merupakan hubungan hukum dalam konteks Hukum Perselisihan. Indikator pembeda dalam Hukum Perselisihan, yaitu:

a) Golongan Rakyat, dalam Hukum Antar Golongan. Maksudnya, apabila para pihak melakukan hubungan hukum itu berasal dari golongan yang berbeda (Pasal 131 dan 163 IS: Golongan Eropa, Golongan Timur Asing dan Golongan Pribumi).

b) Agama masing-masing pihak, dalam Hukum Antar Agama.

c) Adat atau Hukum Adat para pihak, dalam Hukum Antar Adat.

d) Tanah jajahan yang berlainan dari Negara penjajah yang sama, dalam Hukum Antar Regio. hlm.39.
2) Titik Pertautan Sekunder (Titik Taut Penentu)

Titik taut sekunder menurut Dr. Sunarjati Hartono, S.H. adalah faktafakta yang menentukan hukum manakah yang harus berlaku. ${ }^{8}$ Menurut Prof. Dr. S. Gautama, S.H. adalah faktor-faktor dan keadaankeadaan yang menentukan berlakunya suatu sistem Hukum tertentu. Jadi, titik taut sekunder adalah indikator yang menentukan hukum yang berlaku bagi peristiwa hukum dalam konteks Hukum Perselisihan. Indikator Penentu yaitu:

a) Kehendak atau maksud para pihak. Jadi, para pihak bebas memilih hukum diantara hukum para pihak yang akan diberlakukan untuk peristiwa hukum mereka.

b) Pilihan hukum. Jadi, para pihak memilih hukum pihak ketiga (diluar hukum para pihak).

c) Milieu atau lingkungan tempat terjadinya peristiwa atau hubungan hukum.

\footnotetext{
${ }^{8}$ Sunarjati Hartono, Dari Hukum Antar Golongan ke Hukum Antar Adat, (Bandung: PT. Citra Aditya Bakti, 1991), hlm.95.
} 
d) Kedudukan salah satu pihak yang jauh melebihi dari pihak lainnya.

Selain mempertimbangkan titik taut primer maupun sekunder dalam hukum antar golongan, untuk menentukan ketentuan hukum apa yang digunakan menurut penulis juga dapat digunakan teori, pendapat ahli, yurisprudensi serta interpretasi terhadap bunyi pasal yang akan dijabarkan dalam tabel dibawah ini:

\begin{tabular}{|c|c|c|c|}
\hline No & $\begin{array}{l}\text { Landasan } \\
\text { Teoritik }\end{array}$ & Hasil Temuan & Analisis \\
\hline 1. & $\begin{array}{l}\text { Teori Hukum } \\
\text { Antar Golongan }\end{array}$ & $\begin{array}{l}\text { a. Titik Taut Primer } \\
\text { yang menentukan: } \\
\text { Agama dan Adat } \\
\text { para pihak. } \\
\text { b. Titik taut sekunder } \\
\text { yang menentukan: } \\
\text { Mileu dan } \\
\text { kedudukan pihak } \\
\text { yang lebih tinggi. }\end{array}$ & $\begin{array}{l}\text { Berdasarkan lima aspek } \\
\text { tersebut, untuk membagi } \\
\text { harta bersama pada } \\
\text { perkawinan beda agama } \\
\text { yang dicatatkan maka } \\
\text { menurut penulis digunakan } \\
\text { hukum adat dari si suami } \\
\text { apabila sebelumnya tidak } \\
\text { dibuat perjanjian } \\
\text { perkawinan yang } \\
\text { menentukan lain. }\end{array}$ \\
\hline 2. & $\begin{array}{l}\text { Teori Receptie } \\
\text { in complexu }\end{array}$ & $\begin{array}{l}\text { Teori ini menyatukan } \\
\text { kedudukan Hukum } \\
\text { Adat sama dengan } \\
\text { Hukum Agama. }\end{array}$ & $\begin{array}{l}\text { Karena berdasar titik taut } \\
\text { sekunder mengenai } \\
\text { kedudukan pihak yang lebih } \\
\text { tinggi jika dikaitkan dengan } \\
\text { meninjau pasal } 31 \text { dan } 34 \\
\text { UUP maka sebenarnya } \\
\text { dapat dilihat bahwa undang- } \\
\text { undang menempatkan } \\
\text { kedudukan suami dalam } \\
\text { perkawinann lebih tinggi }\end{array}$ \\
\hline
\end{tabular}


daripada kedudukan istri.

Jadi sudah sepatutnya dalam

hal terjadi konflik antar

agama maupun antar adat

dalam perkawinan maka

hukum suami-lah yang

digunakan.

\begin{tabular}{|c|c|c|}
\hline 3. & Pendapat Ahli / & Menurut Mocd. Idris \\
\hline & Doktrin Moch. & Ramulyo, pada \\
\hline & Idris Ramulyo & penjelasan atas Pasal \\
\hline & & 37 UUP ditunjukkan \\
\hline & & kepada artinya, \\
\hline & & hukumnya masing- \\
\hline & & masing, yakni \\
\hline & & jawabannya hukum \\
\hline & & agama, hukum adat, \\
\hline & & maupun hukum \\
\hline & & lainnya, \\
\hline & & konsekuensinya jika \\
\hline & & perkawinan putus \\
\hline & & karena perceraian \\
\hline & & (bukan karena \\
\hline & & kematian) maka harta \\
\hline & & bersama diatur \\
\hline & & menurut Hukum \\
\hline & & Agama. \\
\hline 4. & Yurisprudensi & Perkawinan campuran \\
\hline & Landraad & antara seorang \\
\hline & "Percampuran & perempuan Gorontalo \\
\hline & Dengan Suku & dan seorang laki-laki \\
\hline
\end{tabular}




\begin{tabular}{ll}
\hline Bangsa Asli & Jawa- Islam. Pasangan \\
Perkawinan & tersebut tinggal di \\
Antar Tempat" & Manado, semua \\
di Manado, 5 & anaknya dilahirkan di \\
September 1938 & Manado. Dalam hal \\
& harta perkawinan, \\
& Hukum adat kebiasaan \\
& sang suami yang \\
& digunakan. \\
\hline Konsep Hukum & Berdasarkan bunyi \\
Perkawinan & Pasal 31 maka \\
Pasal 31, 34 & kedudukan suami \\
UUP. & dalam perkawinan \\
& pada hakikatnya lebih \\
& tinggi, hal tersebut \\
& didukung bunyi Pasal \\
& 34 yang menempatkan \\
& istri sebatas pengelola \\
& rumah tangga. \\
\hline
\end{tabular}

1.2.) Pembagian Melalui Gugatan

Pada perkawinan beda agama, melihat latar belakang terjadinya perkawinan tersebut karena berdasarkan adanya penetapan pengadilan, dan pencatatan perkawinannya dilakukan oleh Kantor Catatan Sipil jadi apabila terjadi perselisihan antara para pihak maka pengajuan gugatan pembagian harta bersama melalui pengadilan negeri, walaupun salah satu pihak baik suami atau istri adalah beragama Islam. Pengadilan Negeri melalui yurisprudensi yang berdasarkan UUP, dalam membagi harta bersama adalah secara berimbang sama besarnya antara suami ataupun istri.

Jika tidak ada perjanjian perkawinan, maka harta bawaan otomatis menjadi hak masing-masing 
suami atau istri dan harta bersama akan dibagi dua sama rata diantara keduanya, hal tersebut berdasarkan yurisprudensi yang telah ada. Contoh yurisprudensi yang ada yaitu putusan Mahkamah Agung tanggal 9 Desember 1959 No. 424K/STP/1959, dalam putusan ini ditegaskan: “menurut yurisprudensi Mahkamah Agung dalam hal terjadi perceraian barang gono-gini harus dibagi antara suami dan istri dengan masingmasing mendapat separuh bagian". 9 Tentunya jika ada perjanjian perkawinan, pembagian harta dilakukan berdasarkan ketentuan dalam perjanjian itu. Namun, jika terjadi kesepakatan lain tentang ketentuan pembagian harta bersama oleh kedua pihak maka harus dibuat suatu pernyataan untuk kemudian diserahkan kepada Majelis Hakim yang memeriksa dan memutus perkara pembagian harta bersama tersebut. ${ }^{10}$

\footnotetext{
${ }^{9}$ Abdul Manan, Aneka Masalah Hukum Perdata Islam di Indonesia, (Jakarta: Kencana, 2006), hlm.129.

${ }^{10}$ Rudi Hartono, SH, MH.

Wawancara. 2016. "Wawancara Panmud Perdata PN Malang”. Jln. Jenderal Ahmad Yani Utara No.198, Malang.
}

Persoalan pembagian harta ini dapat diajukan setelah adanya putusan cerai. Suami atau istri harus mengajukan gugatan baru yang terpisah setelah putusan perceraian dikeluarkan pengadilan. Tuntutan pembagian harta bersama tidak dapat dilakukan bersamaan dengan gugatan perceraian. Larangan tentang gugatan cerai yang tidak boleh digabungkan dengan gugatan harta bersama tersebut tercantum dalam putusan Mahkamah Agung Reg. No.1020 K/Pdt/1986.

\section{Dapat Atau Tidaknya Dilakukan Pemilihan Hukum Untuk Menyelesaikan Pembagian Harta Bersama Pada Perceraian Perkawinan Beda Agama}

Pada rumusan masalah yang kedua ini, definisi dapat atau tidaknya dilakukan pemilihan hukum oleh suami istri pada perceraian perkawinan beda agama tersebut berhubungan dengan ketentuan Pasal 37 UUP yaitu dengan mengambil salah satu pilihan berupa hukum adat pihak istri. Di Indonesia terdapat 19 lingkaran hukum adat sehingga permasalahan yang demikian dimungkinkan terjadi. Misalnya saja 
ketika seorang wanita beragama Islam bersuku Jawa menikah dengan laki-laki Hindu Bali atau suku lainnya, karena pada sistem masyarakat adat yang bercorak kekeluargaan patrilineal, matrilineal, parental/ bilateral memiliki beberapa faham tersendiri terhadap harta perkawinan. Pada ketiganya terdapat suatu perbedaan prinsip terhadap aturan harta perkawinan yang meliputi harta bersama didalamnya. Untuk menjawab pertanyaan tersebut penulis menggunakan landasan teori berupa Asas Persamarataan yang dikemukakan oleh Prof. Dr. Hazairin yang disebutkan dalam buku karangan Sudargo Gautama. Menurut prinsip ini, semua sistem hukum yang dipertautkan dalam suatu peristiwa hatah tertentu mempunyai nilai yang sama. Sistemsistem hukum ini tidak ada yang lebih baik daripada yang lain, artinya tidak ada suatu hukum yang lebih unggul daripada yang lain karena semua adalah setaraf. Tidak ada yang lebih berharga, semua nilainya sama. ${ }^{11}$ hlm.219.
Pemilihan hukum oleh para pihak merupakan salah satu titik taut sekunder dalam hukum antar golongan, lebih dikenal dengan "maksud para pihak" (bodeoeling van partijen), jadi untuk melakukan pemilihan hukum dalam pembagian harta bersama tersebut adalah diperbolehkan.

Pilihan hukum dianggap sebagai salah satu factor yang menentukan hukum yang harus berlaku dalam suasana hubungan antar golongan. Prinsip pilihan hukum ini dikenal dengan prinsip "Choice of Law by the Parties". Dalam yurisprudensi di Indonesia dapat dilihat bahwa adanya kepastian tentang diterimanya pilihan hukum dalam hubungan antar golongan oleh para pihak untuk menentukan sendiri hukum yang berlaku bagi mereka, misalnya dalam keputusan Raad van Justitie di Medan tahun 1926, dimana diberlakukan hukum Tiongkok karena suatu perjanjian dibuat di Tiongkok, walaupun para pihak tinggal di Indonesia karena menurut hakim memang ada "maksud para pihak" bahwa hukum setempat dimana perjanjian itu 
dibuat adalah yang mengatur perjanjian mereka itu. ${ }^{12}$

Hukum memiliki azas persamaan kedudukan (hak) dari pada semua sistem hukum yang berlaku di Indonesia. ${ }^{13}$ Azas inilah yang memungkinkan adanya hukum antar golongan. Maka terhadap dilakukannya pilihan hukum untuk menyelesaikan persoalan pembagian harta bersama oleh pasangan perkawinan beda agama adalah diperbolehkan, selama sudah adanya kesepakatan dari mereka berdua. Karena dilakukannya pilihan hukum merupakan salah satu titik taut sekunder yang diakui dalam hukum antar golongan untuk menentukan hukum yang digunakan. Pendapat salah satu ahli hukum yaitu Prof. Dr. Hazairin juga menguatkan hal tersebut, ia mengemukakan segala stelsel hukum yang dipertautkan dalam hukum antar golongan memiliki nilai yang sama.

\section{Simpulan}

Sebagai akhir dari pembahasan penelitian ini, maka dapat diambil kesimpulan sebagai berikut:

\footnotetext{
${ }^{12}$ Ibid., hlm.29.

${ }^{13}$ Sunarjati Hartono, Op.Cit., hlm.81.
}

1) Penyelesaian pembagian harta bersama pada perkawinan beda agama dalam kondisi normal sepatutnya dibagi dengan ketentuan adat dari pihak suami, hal tersebut berdasarkan dari hasil analisis menggunakan teori hukum antar golongan, teori receptie in complexu, pendapat ahli Idris Ramulyo, Yurisprudensi Landraad di Manado serta interpretasi gramatikal terhadap kedudukan suami yang terdapat pada Pasal 31 dan 34 UUP. Dalam hal terjadi gugatan, maka dapat melalui Pengadilan Negeri, gugatan diajukan terpisah setelah adanya putusan perceraian sebagaimana yang tercantum dalam Putusan Mahkamah Agung Reg. No. 1020 K/Pdt/1986.

2) Berkaitan dengan kalimat "hukumnya masing-masing" pada Pasal 37 UUP, untuk membagi harta bersama apabila para pihak tersebut memiliki latar belakang adat yang berbeda dan ingin melakukan pemilihan hukum adalah diperbolehkan, 
karena pemilihan hukum merupakan salah satu titik taut sekunder yang diakui dalam hukum antar golongan dalam menentukan hukum apa yang digunakan, hal itu juga diperkuat Asas Persamarataan yang dikemukakan ahli hukum Prof. Dr. Hazairin.

\section{Saran}

Bagi Pemerintah, tidak diaturnya perkawinan beda agama dan tidak adanya payung hukum yang menjamin hubungan hukum pasangan perkawinan beda agama menurut penulis perlu dilakukan revisi terhadap UUP, karena dalam beberapa hal akan menimbulkan kekaburan hukum, sebagaimana penerapan Pasal 37 UUP terhadap pembagian harta bersama.

\section{Daftar Pustaka}

Abdul Rachmad Budiono, Pengantar Ilmu Hukum, (Malang: Bayumedia Publishing, 2005.

Abu Yasid, Aspek- aspek Penelitian Hukum, Jakarta: Pustaka Pelajar, 2009.

Abdul Manan, Aneka Masalah Hukum Perdata Islam di
Indonesia, Jakarta: Kencana, 2006.

Ahmad Nurcholish, Pernikahan Beda Agama, Jakarta: Komisi Nasional HAM, 2010.

Ahmad Tholabi, Hukum Keluarga Indonesia, Jakarta: Bumi Aksara, 2013.

Asep Saepudin, Hukum Keluarga, Pidana, \& Bisnis, Jakarta: Kencana, 2013.

Budi Susilo. Prosedur Gugatan Cerai. Yogyakarta: Pustaka Yustisia, 2008.

CST Kansil, Pengantar Ilmu Hukum dan Tata Hukum Indonesia, Jakarta: Balai Pustaka, 1989.

Dewi Wulansari, Hukum Adat Indonesia, Bandung: PT. Refika Aditama, 2014.

Eman Suparman, Hukum Perselisihan ( Konflik Kompetensi dan Pluralisme Hukum Orang Pribumi), Bandung : PT. Refika Aditama, 2009.

Happy Susanto, Pembagian Harta Gono-Gini Saat Terjadi Perceraian, Jakarta: Visimedia, 2008.

Hilman Hadikusuma, Hukum Perkawinan Indonesia, Bandung: Mandar Maju, 2007. 


\section{Hukum Perkawinan \\ Adat, Bandung: Citra Aditya Bakti, 1990.
— Hukum Perkawinan Indonesia Menurut Perundangan: Hukum Adat, Bandung: CV Mandar Maju, 2003.

Iman Sudiyat, Hukum Adat Sketsa Asas, Yogyakarta: Liberty, 2007.

J. Satrio, Hukum Harta Perkawinan, Bandung: PT. Citra Aditya Bakti, 1993.

Jaih Mubarok, Modernisasi Hukum Perkawinan di Indonesia, Bandung: Pustaka Bani Quraisy, 2005.
Johnny Ibrahim, Teori dan Metodologi Hukum Normatif, Jakarta: Bayu Media, 2012.

Tim Penyusun Kamus Pusat Pembinaan dan Pengembangan Bahasa. Kamus Besar Bahasa Indonesia Edisi Kedua. Jakarta: Balai Pustaka. 1997.

Lili Rasjidi, Hukum Perkawinan dan Perceraian, Bandung: Remaja Rosdakarya, 1991.

Moh. Idris Ramulyo, Hukum Perkawinan, Hukum Kewarisan, Hukum Acara Peradilan Agama dan Zakat, Jakarta: Sinar Grafika, 2000.
Muhhamad Syaifuddin, Sri Turatmiyah, dan Annalisa Yahanan, Hukum Perceraian, Jakarta: Bumi Aksara, 2013.

Neng Djubaidah, Pencatatan Perkawinan \& Perkawinan Tidak Dicatat, Jakarta: Sinar Grafika, 2012.

Peter Mahmud Marzuki, Penelitian Hukum, Jakarta: Kencana Prenada Media Group, 2009.

Philipus M. Hadjon, Argumentasi Hukum, Yogyakarta: Gadjah Mada University Press, 2014.

R. Soetojo Prawirohamidjodjo, Hukum Orang dan Keluarga, Surabaya: Airlangga University Press, 2000.

Rachmadi Usman, Aspek-Aspek Hukum Perorangan \& Kekeluargaan di Indonesia, Jakarta: Sinar Grafika, 2006.

Rusmin Tumanggor, Perilaku Nikah Beda Agama: Fenomena Masyarakat Jakarta, Jakarta: Lemlit UIN Syarif Hidayatullah, 2014.

Sajuti Thalib, Hukum Kekeluargaan Indonesia, Jakarta: Press UI, 2008.

Sudargo Gautama, Hukum Antar Golongan, Jakarta: PT. 


\author{
Ichtiar Baru Van \\ Hoeve, 1993.
—, Hukum Antar Tata Hukum, Bandung:
Alumni,1977. \\ Sudikno Mertokusumo, Mengenal \\ Hukum, Yogyakarta: \\ Liberty, 2003. \\ , Hukum Acara Perdata \\ Indonesia, Yogyakarta: \\ Liberty, 2006.
}

Sunarjati Hartono, Dari Hukum Antar Golongan ke Hukum Antar Adat, Bandung: PT. Citra Aditya Bakti, 1991.

Sution Usman Adji, Kawin Lari dan Kawin Antar Agama, Yogyakarta: Liberty,1989.

Tan Thong Kie, Studi Notariat dan

Serba- Serbi Praktek

Notaris (Edisi Revisi),

Jakarta: Ichtiar Baru Van

Hoeve, 2007.

Wirjono Prodjodikoro. Hukum

Perkawinan di Indonesia.

Bandung, 1981.

Wirjono Prodjodikoro, Hukum Antar Golongan di

Indonesia, Bandung: Sumur Bandung, 1981.

Yahya Harahap, Kedudukan Kewenangan Dan Acara Peradilan Agama, Jakarta: Sinar Grafika, 2003.

\section{Peraturan Perundang-undangan}

Kitab Undang- undang Hukum Perdata
Undang- Undang Republik Indonesia Nomor 1 Tahun 1974 tentang Perkawinan. Lembaran Negara Republik Indonesia Tahun 1974 Nomor 1. Tambahan Lembaran Negara Nomor 3019.

Kompilasi Hukum Islam (KHI).

\section{Artikel Jurnal}

AA. Ketut Sukranatha, Kedudukan Perempuan Bali Terhadap Harta Bersama Dalam Hal Terjadi Perceraian (Analisis Perkembangan Yurisprudensi), Fakultas Hukum Udayana, Bali, 2015.

Nanik Rukmana, Pelaksanaan Pembagian Harta Bersama (Gono- Gini) Praktek di Pengadilan Agama Mataram, Fakultas Hukum Universitas Mataram, Mataram, 2013.

Ni Ketut Ratini, Tinjauan Hukum Tentang Kedudukan Harta Bersama Setelah Perceraian Menurut Hukum Adat (Studi Kasus Terhadap Orang Bali Beragama Hindu di Kota Palu), Pendidikan Agama Hindu STAH Dharma Sentana, Sulteng, 2015.

Muhhamad Agus Rudianto, Pelaksanaan Pembagian Harta Bersama dalam Praktek di Pengadilan Agama Kelas I A Samarinda, Fakultas Hukum Unmul, Samarinda, 2013. 
Veny Rizki Indahsari, Penyelesaian Sengketa Harta Bersama Melalui Mediasi, Fakultas Hukum Unej, Jember, 2014.

Lieke Ayu Amalia, Tinjauan Yuridis Terhadap Pembagian Harta Asal dan Harta Bersama, Fakultas Hukum Unpad, Bandung, 2011.

Helmy Ziaul Fuad, Kedudukan Harta Bersama dalam Perkawinan Poligami, Fakultas Syariah dan Hukum UIN Sunan Kalijaga, Yogyakarta, 2014.

Syarifah Usman, Optimalisasi Peranan Notaris Dalam Pembuatan Akta Pembagian Harta Suarang Setelah Terjadi Perceraian Berdasarkan Hukum Adat Minangkabau (Studi Kasus Di Kelurahan Air Tawar Timur, Kecamatan Padang Utara, Sumatera Barat), Fakultas Hukum Universitas Brawijaya, Malang, 2015.

Syaiful Alam, Proses Penyelesaian Pembagian Harta Bersama Akibat Perceraian di Pengadilan Agama Kelas I Metro, Fakultas Hukum UGM, Yogyakarta, 1995.

Nia Istiamah, Pembagian Harta Gono- Gini Akibat Perceraian Menurut Hukum Islam, Fakultas Syariah Institut Agama Islam Negeri Semarang, Semarang, 2011.
Etty Rochaety, Analisis Yuridis tentang Harta Bersama dalam Perkawinan menurut Hukum Islam dan Hukum Positif, Sekolah Tinggi Hukum Bandung, Bandung, 2013.

Sri Turatmiyah, Fenomena Perkawinan dan Perceraian Beda Agama menurut Undang- undang Nomor 1 Tahun 1974, Fakultas Hukum Unsri, Palembang, 2013.

Ismy Syafriani Nasution, Akibat Hukum Perceraian Terhadap Harta Bersama berdasarkan Undangundang Perkawinan Nomor 1 Tahun 1974 dan Kompilasi Hukum Islam, Sekolah Pascasarjana Universitas Sumatera Utara, Medan, 2009

\section{Situs Internet}

Arti dan tujuan Perkawinan (online), http://hukumonline.com 